\title{
Absorption Kinetics of Subcutaneously Injected Insulin
}

\author{
Evidence for Degradation at the Injection Site \\ M. Berger ${ }^{1}$, P. A. Halban ${ }^{1}$, L. Girardier ${ }^{2}$, J. Seydoux ${ }^{2}$, R. E. Offord ${ }^{3}$, and A. E. Renold ${ }^{1}$ \\ ${ }^{1}$ Institut de Biochimie Clinique, ${ }^{2}$ Department of Physiology, University of Geneva, Switzerland, and ${ }^{3}$ Laboratory of Molecular Biophysics, \\ Department of Zoology, University of Oxford, England
}

\begin{abstract}
Summary. The absorption of subcutaneously injected insulin was examined by injecting semisynthetic $\left[{ }^{3} \mathrm{H}\right]$ insulin in anaesthetized pigs and subsequently analysing the tissue excised from the injection site. Contrary to previously accepted views, a significant proportion of insulin was degraded at the injection site. The disappearance of intact $\left[{ }^{3} \mathrm{H}\right]$ insulin from the injection site followed a monoexponential function with a half-time of $59 \mathrm{~min}$.
\end{abstract}

Key words: Tritiated insulin, subcutaneous insulin injections, chemical analysis of injection site, absorption kinetics, local insulin degradation.

In previous attempts to assess the absorption of insulin from its subcutaneous depot in man, radioiodinated insulin preparations were injected, and the disappearance of the radioactivity from the injection site measured by an external gamma-counter [1-6]. Among other assumptions, this method depends on there being only negligible local degradation of the injected insulin. When well characterized preparations of highly purified $\left[{ }^{125} \mathrm{I}\right]$ Actrapid ${ }^{\circledR}$-Insulin were used, it was found that the time course of disappearance of ${ }^{125} \mathrm{I}$ from the injection site was linear, at least up to 4 hours $[5,6]$; on injection of $\left[{ }^{125} \mathrm{I}\right]$ Actrapid ${ }^{\circledR}$ Insulin in the leg, mobilization of the first $50 \%$ of the radioactivity took between 160 and $180 \mathrm{~min}[5,6]$. Thus, if these findings are correct, at a time when Actrapid $^{\mathbb{R}}$-Insulin reaches its maximal hypoglycaemic $[7,8]$, only about $1 / 5$ to $1 / 4$ of the injected material has been absorbed from the subcutaneous depot. This apparent discrepancy prompted us to reinvestigate the absorption kinetics of SC injected insulin in anaesthetized pigs using a direct method.

\section{Methods}

Semisynthetic $\left[{ }^{3} \mathrm{H}\right]$ insulin was used; the authenticity of this as a tracer has been discussed elsewhere [9-12]. The $\left[{ }^{3} \mathrm{H}\right]$ insulin was injected SC in anaesthetized pigs and the site of injection excised at intervals thereafter. The excised tissue was subjected to analysis for $\left[{ }^{3} \mathrm{H}\right]$ insulin and its degradation products.

One batch of semisynthetic $\left[{ }^{3} \mathrm{H}\right]$ insulin (pork) was prepared and purified according to Halban and Offord $[9,10]$ and used for all the studies. On the day of the experiment, $\left[{ }^{3} \mathrm{H}\right]$ insulin was repurified by sephadex $\mathrm{G} 50$ column chromatography as described previously [10]. By this method more than $95 \%$ of the radioactivity in the purified $\left[{ }^{3} \mathrm{H}\right]$ insulin is immunoprecipitable [9-12]; the biological activity of the purified $\left[{ }^{3} \mathrm{H}\right]$ insulin (on blood glucose depression in rats) is indistinguishable from native insulin. In the following experiments the specific radioactivity of the labelled insulin was $11 \mathrm{Ci} / \mathrm{mmol}$ and $96 \pm 1 \%$ (Mean $\pm \mathrm{SEM}, \mathrm{n}=4$ ) of the ${ }^{3} \mathrm{H}$ was associated with intact $\left[{ }^{3} \mathrm{H}\right]$ insulin. An amount $(0.9-1.4$ $\times 10^{5} \mathrm{dpm}$ ) of this material, equivalent to $0.5-0.8 \mathrm{mU}$ insulin, was prepared for injection in $0.2-0.3 \mathrm{ml}$ of $0.2 \mathrm{~mol} / \mathrm{l}$ glycine-HCl-buffer, pH 7.4 containing $2.5 \mathrm{~g} / \mathrm{l}$ bovine serum albumin (BSA). In some experiments, 10 units of crystalline pork insulin was included in the injected solution. In all cases, Dextran Blue ${ }^{\circledR}$ (Pharmacia) was added to the solution $(20 \mathrm{~g} / 1)$ to facilitate location of the injected material during excision of the site. Preliminary experiments had shown that dispersion of the injected material in the subcutaneous adipose tissue was quite variable.

The mixtures were injected subcutaneously at several sites in the abdominal and the gluteal regions of overnight-fasted pigs (weight $123 \pm 14 \mathrm{~kg}, \mathrm{n}=6$ ) anaesthetized with Methonidate Hydrochloride, $8 \mathrm{mg} / \mathrm{kg}$, following premedication with Atropin $0.02 \mathrm{mg} / \mathrm{kg}$ and Sresnil $2 \mathrm{mg} / \mathrm{kg}$. The sites were approximately $12 \mathrm{~cm}$ apart. At set times between 15 and $160 \mathrm{~min}, 3$ to $5 \mathrm{~g}$ subcutaneous tissue around the injection site was excised en bloc and divided into portions of approximately $1 \mathrm{~g}$ according to the distribution of the dye: two portions were intensely coloured, one slightly coloured, and a fourth portion uncoloured. No blue material was left in the animal. The tissue pieces were immediately solubilized in $2 \mathrm{~g} / 100 \mathrm{ml}$ sodium-dodecylsulphate (SDS) and aliquots of the extracts were subjected to routine counting procedures in a liquid scintillation counter using Instagel ${ }^{\sqrt{B}}$ as the scintillant. The minimum radioactivity counted per $\mathrm{ml}$ tissue extract was $500 \mathrm{cpm}$. Once the counts had been recorded a ${ }^{3} \mathrm{H}$ standard was added to assess the quenching in each individual tube. Most (94 \pm $1 \%$ ) of the extractable ${ }^{3} \mathrm{H}$ was localized in the coloured biopsy portions. Aliquots of these soluble extracts were assayed for 


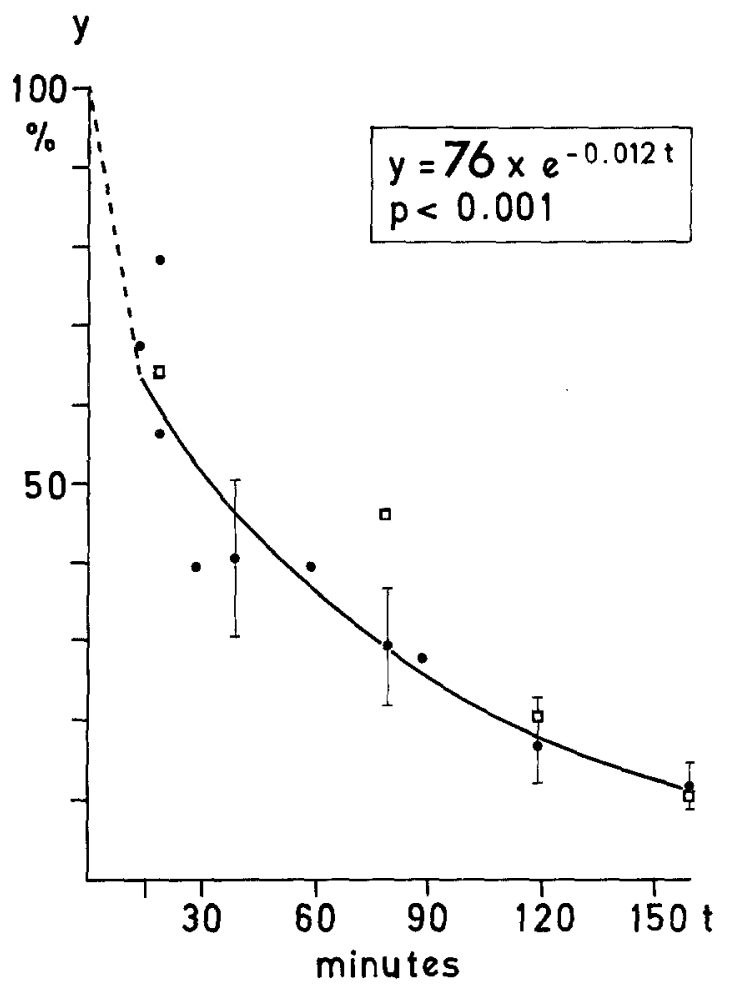

Fig. 1. Disappearance of $\left[{ }^{3} \mathrm{H}\right]$ insulin (y) from the subcutaneous injection site in anaesthetized pigs against time after injection $(\mathrm{t})$. $y$ is given in \% of the injected dose of $\left[{ }^{3} \mathrm{H}\right]$ insulin; the correlation function is calculated on the basis of $n=19$ individual observations. $=$ individual observations and Mean \pm SEM of 3 to 4 observations for experiments with injections of $\left[{ }^{3} \mathrm{H}\right]$ insulin. $\square=$ individual observations for experiments with addition of $10 \mathrm{U}$ unlabelled pork insulin to the injected solution of $\left[{ }^{3} \mathrm{H}\right]$ insulin. (These data are not included in the calculation of the correlation)

degradation of $\left[{ }^{3} \mathrm{H}\right]$ insulin using column chromatography on G-75 Sephadex (fine grade, Pharmacia) with $20 \mathrm{~g} / 1 \mathrm{SDS}$, and $5 \mathrm{~g} / 1 \mathrm{BSA}$ as eluant. As described previously [12], intact $\left[{ }^{3} \mathrm{H}\right]$ insulin can be separated in this way from its labelled high-molecular-weight- and low-molecular-weight degradation products. Neither handling of the tissue nor the addition of Dextran Blue altered the elution profile of $\left[{ }^{3} \mathrm{H}\right]$ insulin. Thus the purity of the $\left[{ }^{3} \mathrm{H}\right]$ insulin solution before injection was $96 \pm 1 \%$ : when an aliquot of $\left[{ }^{3} \mathrm{H}\right]$ insulin was added to $10 \mathrm{ml}$ SDS containing solubilized pig adipose tissue and Dextran Blue, subsequent chromatography revealed that $97.3 \%$ of the ${ }^{3} \mathrm{H}$ was still present as intact $\left[{ }^{3} \mathrm{H}\right]$ insulin. In addition, $\left[{ }^{3} \mathrm{H}\right]$ insulin and Dextran Blue were injected into $0.8 \mathrm{~g}$ adipose tissue immediately after its excision from an anaesthetized pig; this tissue piece was then treated according to the experimental protocol and chromatography of the solubilized tissue extracts showed that $97 \%$ of the ${ }^{3} \mathrm{H}$ still eluted in the position of intact $\left[{ }^{3} \mathrm{H}\right]$ insulin.

\section{Results}

The disappearance of total radioactivity of $\left[{ }^{3} \mathrm{H}\right]$ insulin (Table 1 ) is described by the mono-exponential function $y^{\prime}=92 \times \mathrm{e}^{-0.012 t}$ where $\mathrm{y}^{\prime}$ is the radioactivity recovered by biopsy of the injection site expressed as a percentage of the amount of ${ }^{3} \mathrm{H}$ which had been injected, and $t$ is the time interval in minutes after the injection. Thus, assuming mono-exponential decay
Table 1. Recovery of ${ }^{3} \mathrm{H}$ from the subcutaneous injection site and local degradation of $\left[{ }^{3} \mathrm{H}\right]$ insulin following its injection into anaesthetized pigs

\begin{tabular}{rlll}
$\begin{array}{l}\text { Time after } \\
\text { injection } \\
\text { (min) }\end{array}$ & $\mathrm{n}$ & $\begin{array}{l}{ }^{3} \mathrm{H} \text { radioactivity recovered } \\
\text { from the injection site } \\
\text { (\% of injected dose) }\end{array}$ & $\begin{array}{l}\% \text { local } \\
\text { degradation }\end{array}$ \\
\hline 15 & 1 & 83 & 21 \\
20 & 2 & 96,69 & 14,26 \\
30 & 1 & 49 & 23 \\
40 & 3 & $50 \pm 12$ & $22 \pm 6$ \\
60 & 1 & 49 & 21 \\
80 & 3 & $37 \pm 9$ & $12 \pm 2$ \\
90 & 1 & 34 & 24 \\
120 & 4 & $21 \pm 6$ & $29 \pm 7$ \\
160 & 3 & $14 \pm 3$ & $19 \pm 3$ \\
& & & mean $21 \pm 2^{\mathrm{b}}$ \\
\hline
\end{tabular}

Means $\pm S E M$ are given where appropriate

a Assessed chromatographically as described in the text

b Value significantly different $(\mathrm{p}<0.001)$ from the initial impurity of the $\left[{ }^{3} \mathrm{H}\right]$ insulin in the injected solution $(4 \pm 1 \%, \mathrm{n}=4)$

throughout, the half-time of disappearance of ${ }^{3} \mathrm{H}$ following the injection was $59 \mathrm{~min}$. One hour after the injection of $\left[{ }^{3} \mathrm{H}\right]$ insulin only $45 \%$ of the radioactivity was recoverable from the injection site.

Chromatographic evaluation of the solubilized extracts revealed a degradation of $\left[{ }^{3} \mathrm{H}\right]$ insulin of 21 $\pm 2 \%($ Mean \pm SEM, $\mathrm{n}=19)$, expressed as a percentage of the recovered ${ }^{3} \mathrm{H}$ (Table 1$)$. Since the extent of degradation was independent of the time interval after the injection, approximately $1 / 5$ of the administered insulin will have been degraded within the first $15 \mathrm{~min}$ following the injection. Highmolecular-weight degradation products tended to increase and the low-molecular-weight fraction to decrease with time; these changes did, however, not reach statistical significance. Nevertheless, degradation products of low molecular weight might be cleared from the site more rapidly than intact insulin: our estimate of the extent of degradation at any time is based only on material that remains at the site and should therefore be regarded as a minimum value.

If the intact $\left[{ }^{3} \mathrm{H}\right]$ insulin recovered from the injection site (total ${ }^{3} \mathrm{H}$ corrected for tritiated degradation products, table 1) expressed as percent of the dose of intact $\left[{ }^{3} \mathrm{H}\right]$ insulin injected at zero time (total injected dose of ${ }^{3} \mathrm{H}$ corrected for the initial impurity of $4 \pm$ $1 \%$ ) is plotted against the time, the disappearance of intact $\left[{ }^{3} \mathrm{H}\right]$ insulin from the injection site can be calculated (Figure 1). This is also a monoexponential function, $y=76 \times \mathrm{e}^{-0.012 \mathrm{t}}(\mathrm{p}<0.001)$. The addition of $10 \mathrm{U}$ unlabelled pork insulin to the injected solution, examined at four different time points (Figure 1), did not alter the rate of disappearance of $\left[{ }^{3} \mathrm{H}\right]$ insulin from the subcutaneous injection site. Thus, $50 \%$ of the injected insulin had disappeared from the injection site at $35 \mathrm{~min}$, due both to local degradation and to mobilization. 


\section{Discussion}

In contrast to previous attempts to measure the absorption of subcutaneously injected insulin by indirect methods [1-6], this study reveals a mono-exponential time curve for the disappearance of insulin from its subcutaneous injection site in pigs; the first $50 \%$ of the insulin dose administered disappeared from the injection site after $35 \mathrm{~min}$. Such a time course of insulin disappearance albeit derived from anaesthetized pigs - corresponds well with the kinetics of the appearance of ${ }^{3} \mathrm{H}$ insulin in the blood after SC injection of the tracer in diabetic patients [13], and with the time course of the hypoglycaemic effect after SC insulin injections of short-acting soluble insulin $[7,8]$.

The significant degradation of insulin at the subcutaneous injection site shown in this study is in accordance with the demonstration of a specific insulin-degrading enzyme in adipose tissue [14]. We have recently shown approximately $50 \%$ degradation of $\left[{ }^{3} \mathrm{H}\right]$ insulin over one hour when $0.5 \mathrm{mU}$ of insulin was incubated at $37^{\circ} \mathrm{C}$ with $1 \mathrm{~g}$ of rat adipose tissue in $1.5 \mathrm{ml}$ Krebs-Ringer-Bicarbonate buffer containing albumin. This degradation decreased to $10 \%$ when $1 \mathrm{U}$ of pork insulin was added to the incubation mixture. In preliminary studies, degradation was also observed when $\left[{ }^{3} \mathrm{H}\right]$ insulin was injected into an isolated piece of pig subcutaneous tissue incubated at $37^{\circ} \mathrm{C}$.

The demonstration that subcutaneously injected insulin is locally degraded is of particular clinical interest since it may explain the increased hypoglycaemic effect of IV insulin compared to equivalent doses given SC in diabetic man [15-17] and animals [18]. If such degradation also occurs in man, it may differ considerably between different injection sites and from one patient to another. This may be a cause for otherwise unexplained variations in insulin requirements among juvenile type diabetics.

Note added in proof: Recently we have demonstrated that the degradation of $\left[{ }^{3} \mathrm{H}\right]$ insulin by adipose tissue in vitro is inhibited by ophthalmic acid and by Trasylol (Bayer AG, Germany), a pancreatic protease inhibitor. [Offord, Philippe, Daries, Halban, Berger: Biochem. J. (in press)].

Acknowledgements. This study was supported by the Swiss National Science Foundation Grant No. 3774-0.76R, and by the Medical Research Council of the United Kingdom. The authors gratefully acknowledge the expert technical assistance of Ms. Susan Suter, Jarmila Slesinger and Dominique Coup and of Mr. Asllan Gjinovci; they thank Professors Hahn and Belenger, Laboratory of Cardiovascular Surgery, University of Geneva, for their co-operation.

\section{References}

1. Moore, E. W., Mitchell, M. L., Chalmers, T. C.: Variability in absorption of insulin- ${ }^{131} \mathrm{I}$ in normal and diabetic subjects after subcutaneous and intramuscular injection. J. Clin. Invest. 38, 1222-1227 (1959)

2. Balodimos, M. C., Williams, R. H.: Absorption of insulin- ${ }^{131}$ I from subcutaneous tissue in diabetic patients. Am. J. Med. Sci. 243, 103-149, 110-156 (1962)

3. Nora, J. J., Smith, D. M., Cameron, J. R.: The route of insulin administration in the management of Diabetes Mellitus. J. Pediatr. 64, 547-551 (1964)

4. Joiner, C. L.: Rate of clearance of insulin labelled with ${ }^{131}$ I from the subcutaneous tissues in normal and diabetic subjects. Lancet 1959 I, 964-967

5. Binder, C.: Absorption of injected insulin. Acta Pharmacol. Toxicol. [Suppl. 2] (Kbh.) 27, 1-87 (1969)

6. Koivisto, V.A., Felig, P.: Effects of leg exercise on insulin absorption in diabetic patients. N. Engl. J. Med. 298, 77-83 (1978)

7. Schöffling, K., Müller, R.: Die klinische Wirkung der InsulinZubereitungen. In: Insulin, Part 1, Handbook of experimental pharmacology. Dörzbach, E. (Ed.), pp. 321-338. Berlin, Heidelberg, New York: Springer 1971

8. Schlichtkrull, J., Pingel, M., Heding, L. G., Brange, J., Jorgensen, K. H.: Insulin preparations with prolonged effect. In: Insulin, Part 2, Handbook of experimental pharmacology. Hasselblatt, A., Bruchhausen, F. von (Eds.), pp. 729-777 Berlin, Heidelberg, New York: Springer 1975

9. Halban, P. A., Offord, R. E.: The preparation of a semisynthetic tritiated insulin with a specific radioactivity of up to 20 Curies per millimole. Biochem. J. 151, 219-225 (1975)

10. Halban, P. A., Karakash, C., Davies, J. G., Offord, R. E.: The degradation of semisynthetic tritiated insulin by perfused mouse livers. Biochem. J. 160, 409-412 (1976)

11. Berger, M., Halban, P. A., Müller, W. A., Offord, R.E., Renold, A. E., Vranic, M.: Mobilization of subcutaneously injected tritiated insulin in rats: effects of muscular exercise. Diabetologia 15, 133-140 (1978)

12. Halban, P. A., Berger, M., Gjinovci, A., Vranic, M., Renold, A. E., Offord, R. E.: Pharmacokinetics of subcutaneously injected semisynthetic tritiated insulin in rats. In: International Meeting on Protein Semisynthesis. Offord, R. E., di Bello, C. (Eds.), pp. 237-247. New York: Academic Press 1978

13. Berger, M., Halban, P. A., Assal, J.-P., Offord, R. E., Vranic, M., Renold, A. E.: Pharmacokinetics of subcutaneously injected tritiated insulin: Effects of exercise. Diabetes $\mathbf{2 8}$ (Suppl. 1), 53-57 (1979)

14. Chandler, M. L., Varandani, P. T.: Insulin degradation 11. The widespread distribution of glutathione-insulin-transhydrogenase in the tissues of the rat. Biochim. Biophys. Acta 286, 136-145 (1972)

15. Pfeiffer, E. F.: Development and future aspects of an artificial Beta-cell system. In: Diabetes research today. Renold, A. E., Creutzfeldt, W., Pfeiffer, E. F. (Eds.), pp. 259-299. Stuttgart, New York: Schattauer Verlag 1976

16. Pickup, J. C., Keen, H., Parsons, J. A., Alberti, K. G. M. M.: Continuous subcutaneous insulin infusion. An approach to achieving normoglycaemia. Br. Med. J. 1978 I, 204-207

17. Dandona, P., Foster, M., Healey, F., Greenbury, E., Beckett, A. G.: Low-dose insulin infusions in Diabetic patients with high insulin requirements. Lancet $1978 \mathrm{II}, 283-285$

18. Stevenson, R. W., Tsakok, T. I., Parsons, J. A.: Partial inactivation of insulin injected or infused subcutaneously to rats. Diabetologia 15, 272 (1978) (Abstract)

Received: October 9, 1978, and in revised form: March 15, 1979

Prof. Dr. M. Berger

II. Medizinische Universitätsklinik

Moorenstraße 5

D-4000 Düsseldorf

Federal Republic of Germany 